\title{
FREDHOLM ALTERNATIVE FOR THE SECOND ORDER DIFFERENTIAL OPERATOR ASSOCIATED TO A CLASS OF BOUNDARY CONDITIONS
}

\author{
Do Huy HoAng And LE XUAN TRUONG
}

Abstract. This work is concerned with the Fredholm property of the second order differential operator associated to a class of boundary conditions. Several sufficient conditions will be proved along with constructing the generalized inverse for such operator. The result is a basic tool to analysis the boundary value problems at resonance for nonlinear perturbation of such operators.

Mathematics subject classification (2010): 34B10, 34B15.

Keywords and phrases: Fredholm property, second order differential operator, continuation theorem, projector, generalized inverse.

\section{REFERENCES}

[1] L. Cesari, Functional analysis, nonlinear differential equations and the alternative method, Proc. Conf., Mich. State Univ., East Lansing, Mich., 1975, pp. 1-197.

[2] W. Feng AND J. R. L. WebB, Solvability of three-point boundary value problems at resonance, Nonlinear Analysis TMA, 30 (1997), 3227-3238.

[3] W. FenG, J. R. L. WeBB, Solvability of m-point boundary value problems with nonlinear growth, J. Math. Anal. Appl., 212 (1997), 467-480.

[4] R. E. Gaines, J. Mawhin, Coincidence Degree and Nonlinear Differential Equations, 568, Lecture Notes in Math., Springer-Verlag, Berlin, 1977.

[5] H. G. Gebran, C. A. Stuart, Exponential decay and Fredholm properties in second-order quasilinear elliptic systems, J. Differential Equations, 249 (2010), 94-117.

[6] D. Gheorghe, F. H. Vasilescu, Quotient morphisms, compositions, and Fredholm index, Linear Algebra and its Applications, 431 (2009), 2049-2061.

[7] C. P. GUPTA, Existence theorems for a second order m-point boundary value problem at resonance, Int. J. Math. \& Math. Sci., 18 (1995), 705-710.

[8] V. A. IL'IN, E. I. MoISEEv, Nonlocal boundary value problem of the first kind for a Sturm-Liouville operator, J. Differential Equations, 23 (1987), 803-810.

[9] R. Kannan, Perturbation methods for nonlinear problems at resonance, Proc. Conf., Mich. State Univ., East Lansing, Mich., 1975, 209-225.

[10] N. Kosmatov, A singular non-local problem at resonance, J. Math. Anal. Appl., 394 (2012), 425431.

[11] Y. LatUSHKIN AND Y. TOMILOv, Fredholm differential operators with unbounded coefficients, J. Differential Equations, 208 (2005), 388-429.

[12] R. MA, Existence results of a m-point boundary value problem at resonance, J. Math. Anal. Appl., 294 (2004), 147-157.

[13] P. D. Phung, L. X. TRuong, On the existence of a three point boundary value problem at resonance in $\mathbb{R}^{n}$, J. Math. Anal. Appl., 416 (2014), 522-533.

[14] A. Pogan And A. Shell, Fredholm properties of radially symmetric, second order differential operators, Int. J. Dyn. Sys. Diff. Eqns., 3 (2011), 289-327.

[15] P. J. RABIER, Fredholm operators, semigroups and the asymptotic and boundary behavior of solutions of PDEs, J. Differential Equations, 193 (2003), 460-480.

[16] V. VOUGALTER AND V. VOLPERT, On the existence of stationary solutions for some non-Fredholm integro-differential equations, Documenta Mathematica, 16 (2011), 561-580. 
[17] S. A. WiLliams, A sharp sufficient condition for solution of nonlinear elliptic boundary value problem, J. Differential Equations., 8 (1970), 580-586.

[18] X. ZhAng, M. Feng, W. GE, Existence result of second-order differential equations with integral boundary conditions at resonance, J. Math. Anal. Appl., 353 (2009), 311-319. 